\title{
Preparation and Characterization of Monoclonal Antibodies Directed Against Antigenic Determinants of Recombinant Human Tumour Necrosis Factor (rTNF)
}

\author{
ANTHONY MEAGER, SHARAN PARTI, HELEN LEUNG, \\ ELIZABETH PEIL, and BERNARD MAHON \\ Division of Immunobiology, National Institute for Biological Standards and Control, \\ Holly Hill, Hampstead, London NW3 6RB, United Kingdom
}

\begin{abstract}
A large number of monoclonal antibodies (McAb) binding to antigenic determinants of human tumour necrosis factor (TNF) were prepared from two fusions of mouse myeloma NSo cells with spleen cells from Balb/c mice immunized with highly purified recombinant ( $r$ ) TNF. Several of these McAbs were highly neutralizing with respect to the biological activity (cytotoxicity) of TNF manifested in L-929 Cl.10 cells. Antibody competition experiments suggested the presence of at least two antigenic determinants on the rTNF molecule through which binding of McAb effects neutralization of biological activity. Some of these McAbs were shown to be suitable for the development of immuoassays to quantify rTNF.
\end{abstract}

\section{INTRODUCTION}

Carswell et al (1) identified a cytotoxin (CTX) in the sera of mice infected with Bacillus Calmette-Guerin (BCG) and subsequently treated with endotoxin which they called TNF because of its ability to induce selective tumour necrosis. It has been subsequently found that activated macrophages are the major cellular source of TNF (2) and that, in addition to its selective cytotoxicity, it has other profound biological effects (3). Several of these effects have been ascertained using highly purified rTNF derived from E.coli $(4,5)$. The availability of TNF-specific neutralising antibodies has also aided elucidation of the various biological properties of TNF (6-10). In this study we set out to prepare anti-human TNF monoclonal antibodies (McAbs), for which, to our knowledge, there are as yet few reports on their actual preparation and characterization $(11,12)$, in order to learn more about the antigenic structure of TNF and to prepare reagents for TNF quantification by immunoassay. 
Recombinant human TNF (BASF Knoll AG, Ludwigshafen, FRG; $1.5 \times 10^{7}$ units/mg protein) was used in all studies. Polyclonal antiserum was produced in rabbits immunised intramuscularly (im) with $100 \mu \mathrm{g}$ rTNF in Freund's complete adjuvant (FCA) and subsequently boosted at 4-6 week intervals with the same dose of rTNF in incomplete Freund's adjuvant (IFA). Serum from successive bleeds was tested in TNF-neutralisation assays (see below) and the most potent serum samples combined and purified by ammonium sulphate precipitation followed by gel filtration in Ultrogel ACA44 (LKB). Anti-rTNF McAbs were prepared by the Köhler and Milstein (13) technique following immunisation of young $\mathrm{Balb} / \mathrm{C}$ mice with $50 \mu \mathrm{g} \mathrm{rTNF}$

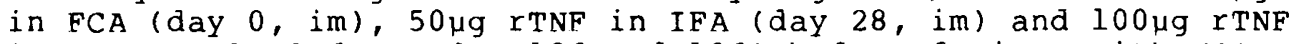
intravenously 3 days (day 126 and 196) before fusions with NSo were carried out. Hybridoma wells were screened by solution phase immunoprecipitation tests (IPT) (14) using 125 I-rTNF labelled by reaction with Enzymobead reagent (Bio-Rad Laboratories, Richmond, CA, USA) to preserve biological activity of rTNF. Hybridoma cells from positive wells were cloned in semi-solid agar, anti-rTNF McAb producing clones identified by 125 I-rTNF IPT, recloned and subsequently expanded for cryopreservation and ascitic fluid production. Immunoglobulin subclass determination was carried out using standard procedures.

\section{TNF Cytotoxicity Assays}

L929 Cl.10 cell monolayers in microtitre trays were stained after $24 \mathrm{~h}$ incubation in medium containing rTNF plus actinomycin $D$ (AMD; $1 \mu \mathrm{g} / \mathrm{ml}$ ) with amido blue black (30 min; 0.058 in $0.1 \mathrm{M}$ sodium acetate -98 acetic acid), fixed ( $10 \mathrm{~min} ; 0.1 \mathrm{M}$ sodium acetate-9\% acetic acid-108 formaldehyde), dye re-extracted in $0.05 \mathrm{M} \mathrm{NaOH}$ and absorbances read at $620 \mathrm{~nm}$ in a Titertek Multiskan. Titres were interpolated from dose response curves, the end-point being defined as the median absorbance or $\mathrm{OD}_{620}$ on the scale of dye uptake measurements that range between those of untreated cells (negative control) and those killed with a high dose of rTNF (positive control). A laboratory reference preparation of rTNF was was included in all assays. To estimate the neutralizing capacity of rabbit polyclonal anti-rTNF and anti-rTNF McAbs, serial antibody dilutions were first incubated with rTNF, at a concentration just sufficient to kill all of the L-929 Cl.10 cells, in medium containing AMD for $2 \mathrm{~h}$ at $370^{\circ} \mathrm{C}$. These diluted antibody-rTNF mixtures were then transferred to preformed $\mathrm{L}-929 \mathrm{Cl} .10$ monolayers and cytotoxicity assays processed as described previously. Antibody neutralizing titre was defined as the reciprocal of that antibody dilution giving the median $\mathrm{OD}_{62} 20$ measurement on the scale of dye uptake measurements that range between positive and negative controls.

\section{Immunoassays to Quantify TNF}

(i) imunoradiometric assay (IRMA) This was adapted from a method described by secher (15) for the quantification of human interferon alpha (HuIFN $r)$. Briefly, $6.5 \mathrm{~mm}$ diameter etched polystyrene beads coated with purified rabbit polyclonal anti-rTNF or anti-rTNF MCAb $(100 \mu \mathrm{g}$ protein per ml in PBS) were incubated with serial dilutions of rTNF reference preparation for $4 \mathrm{~h}$ at $4{ }^{\circ} \mathrm{C}$, washed three times and then incubated with $125 \mathrm{I}-2.33 . \mathrm{G} 2$ or ${ }^{125} \mathrm{I} 2.101 .23$ anti-rTNF MCAb, 
radioiodinated by the chloramine $\mathrm{T}$ method (16), for $16 \mathrm{~h}$ at $4^{\circ} \mathrm{C}$. The beads were re-washed and counted in an LKB gamma counter.

(ii) enzyme-linked immunosorbent assay (ELISA) Purified rabbit polyclonal anti-rTNF diluted $1: 30$ in PBS was coated on U-bottomed polyvinyl chloride (PVC) microtitre plates (Dynatech), 50 $\mathrm{l} /$ well, for $2 \mathrm{~h}$ at $37^{\circ} \mathrm{C}$. Remaining sites in wells were blocked with 28 BSA-PBS, $150 \mu 1$ per well, overnight at $4^{\circ} \mathrm{C}$. Excess antibodies and blocking buffer were then removed and wells washed 4 times with 0.058 Tween 20 (TW20)-PBS. Following the last wash, serial

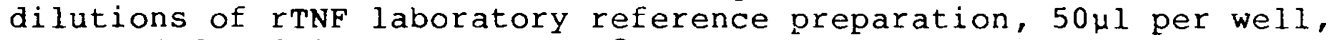
were added and incubated at $37^{\circ} \mathrm{C}$ for $1 \mathrm{~h}$. Wells were washed again 4 times with TW20-PBS followed by (a) addition of purified anti-rTNF

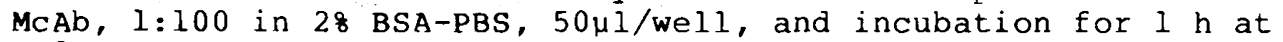
$37^{\circ} \mathrm{C}$, (b) washing with Tw20-PBS and addition of biotinylated sheep anti-mouse immunoglobulin (Amersham International, UK), 1:500 in 28 BSA-PBS, $50 \mu \mathrm{l} /$ well and incubation for $1 \mathrm{~h}$ at $37^{\circ} \mathrm{C}$, (C) washing with TW20-PBS and addition of streptavidin biotinylated horseradish peroxidase complex (Amersham International, UK), $1: 500$ in 28 BSA-PBS, $50 \mu \mathrm{l} /$ well and incubation for $30 \mathrm{~min}$ at $37^{\circ} \mathrm{C}$, (d) washing with TW20-PBS (twice) and 0.1M citrate/phosphate buffer, pH 5.0, (twice) and addition of substrate, orthophenylenediamine (OPD), $\mathrm{lmg} / \mathrm{ml}$, in $0.1 \mathrm{M}$ citrate/phosphate buffer, $\mathrm{pH} \mathrm{5.0,} \mathrm{containing} 0.0068$ hydrogen peroxide $\left(\mathrm{H}_{2} \mathrm{O}_{2}\right)$. Colour (yellow) was developed in the dark for $30 \mathrm{~min}$ at room temperature and the reaction terminated by addition of $50 \mathrm{\mu l} 1 \mathrm{M} \mathrm{H}_{2} \mathrm{SO}_{4}$ to each well. Optical densities were read at $450 \mathrm{~nm}$ in a Titertek Multiskan.

\section{RESULTS AND DISCUSSION}

Screening of two fusions by 125 I-rTNF IPT showed that 90 of 760 wells contained anti-rTNF McAb-secreting hybridomas. Only about $15 \%$ of these produced supernatants with significant neutralising capacity against the cytotoxicity of rTNF. Some 27 of the 90 positives were cloned, with emphasis being placed on obtaining the most potent neutralising McAbs. This process yielded 24 stable hybridoma clones, 13 of which, when grown as ascites, produced highly neutralising anti-rTNF McAbs (Table 1 ). The latter were of comparable potency to rabbit polyclonal anti-rTNF which titred at $24000 \mathrm{nu} / \mathrm{ml}$. All of the anti-rTNF MCAbs so far tested, whether of high or low neutralising capacity, were mouse IgGl subclass.

2.33.G2 and 3.101.23 anti-rTNF McAbs were purified from ascitic fluid by protein A-sepharose chromatography (17) and labelled with 125 I using the chloramine-T method (16). These radio-iodinated McAbs were used in antibody competition experiments (Table 1) which showed that anti-rTNF McAbs could be segregated into three broad groups (Table 1), suggesting the existence of three or more antigenic determinants or epitopes in the rTNF molecule. Highly neutralising anti-rTNF McAbs were divided between the epitope recognised by 2.33 .62 and that recognised by 3.101 .23 (Table 1 ), whilst the majority of low and non-neutralising McAbs, which did not compete out the binding of either radio-iodinated McAb, presumably bound to one or more different epitopes. Neutralisation of rTNF cytotoxicity probably occurs because antibody-binding sterically inhibits rTNF molecules attaching to their cell surface receptors. Alternatively, that such neutralisation can occur through McAbs binding to two or more separate epitopes suggests that two or more distinct areas or sites on the rTNF molecule might be necessary for receptor binding.

L-cell cytotoxicity assays for rTNF are quite easily performed, 
TABLE 1 NEUTRALISATION OF TTNF BY MONOCLONAL ANTIBODIES AND EPITOPE ANALYSIS OF TTNF†

\begin{tabular}{|c|c|c|c|c|c|}
\hline \multicolumn{2}{|c|}{$\begin{array}{l}\text { Epitope } 1 \\
\text { (defined by } \\
\text { binding of } \\
125 \mathrm{I}-2.33 . \mathrm{G} 2 \text { ) }\end{array}$} & \multicolumn{2}{|c|}{ 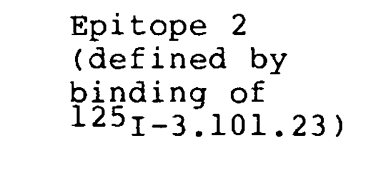 } & \multicolumn{2}{|c|}{$\begin{array}{l}\text { Other epitopes } \\
\text { (not recognised } \\
\text { by either } \\
125 \mathrm{I}-2.33 . \mathrm{G} 2 \text { or } \\
3.101 .23\end{array}$} \\
\hline $\mathrm{MCAb}$ & $\mathrm{nu} / \mathrm{ml}$ & $\mathrm{McAb}$ & $\mathrm{nu} / \mathrm{ml}$ & $\mathrm{MCAb}$ & $\mathrm{nu} / \mathrm{ml}$ \\
\hline $\begin{array}{l}2.33 . \mathrm{G} 2 \\
2.178 . \mathrm{B} 8 \\
2.179 . \mathrm{F} 9 \\
3.6 .10 \\
3.6 .35 \\
3.22 .14 \\
3.13 .7 \star \\
3.27 .2 \star \\
3.34 .16 \star \\
3.51 .17 \star \\
3.129 .16 \star\end{array}$ & $\begin{array}{r}24000 \\
12000 \\
24000 \\
8000 \\
960 \\
960 \\
10000 \\
12000 \\
80 \\
12000 \\
12000\end{array}$ & $\begin{array}{l}3.88 .2 \\
3.88 .34 \\
3.101 .23 \\
3 . \mathrm{D1} .11 \\
3 . \mathrm{C} 9.12 \star\end{array}$ & $\begin{array}{l}24000 \\
56000 \\
24000 \\
12000 \\
32000\end{array}$ & $\begin{array}{l}2.28 .06 \\
3.49 .20 \\
3.76 .22 \\
3.165 .48 \\
3.167 .24 \\
3.176 .17 \\
3.181 .11 \\
3 . E 5.23\end{array}$ & $\begin{array}{r}1500 \\
80 \\
80 \\
320 \\
390 \\
60 \\
<10 \\
<10\end{array}$ \\
\hline
\end{tabular}

† Polyvinyl chloride microtitre plates were coated with rabbit polyclonal anti-rTNF as described for ELISA. Following washing, rTNF, $10^{4} \mathrm{u} / \mathrm{ml}$, was added, $50 \mu \mathrm{l} /$ well, to all wells and incubated for $\mathrm{l} \mathrm{h}$ at $37^{\circ} \mathrm{C}$. Wells were then washed thoroughly with Tw20-PBS and anti-rTNF McAbs as supernatant culture fluid or dilutions of ascitic fluid added to the plate, $50 \mu \mathrm{l} /$ well, and incubated for $1 \mathrm{~h}$ at $37^{\circ} \mathrm{C}$. Wells were again washed thoroughly and theh the competing 125 I-antirTNF MCAb added to all wells $\left(50 \mu l\right.$ containing $\left.1-2 \times 10^{5} \mathrm{cpm} / \mathrm{well}\right)$. Following further incubation for $I_{\mathrm{h}}$ at $37^{\circ} \mathrm{C}$ and washing, wells were cut from the plate with a hot wire and counted in an LKB gamma counter. Negative control (no competition), $4 \times 10^{3} \mathrm{cpm}$; positive control (full competition, eg 125 I-2.33.G2 against cold 2.33.G2) $2 \times 10^{2} \mathrm{cpm}$.

* Indicates that these McAbs partially compete binding of radioiodinated anti-rTNF McAbs

$\mathrm{nu} / \mathrm{ml}$ - neutralising units per $\mathrm{ml}$

but nevertheless tend to produce variable results. For instance, purified $\mathrm{rTNF}(1 \mathrm{mg} / \mathrm{ml})$ titred at $5 \times 10^{7}$ units/ml, somewhat higher than the manufacturer's estimate, in our $\mathrm{L}-929 \mathrm{Cl} .10$ cells. Immunoassays, and in particular IRMA, have proved to be valuable alternative assays for many biologically active proteins, eg interferons $(15,18)$. Using a method previously described for HuIFN (15), rTNF-specific polyclonal antibodies attached to etched polystyrene beads were first incubated with rTNF (0.1-5000 units/ml; $2-105 \mathrm{pg} / \mathrm{ml}$ ) and secondly with $125_{\mathrm{I}-\mathrm{anti}-\mathrm{rTNF} \text { McAb. Typical }}$ calibration curves, plotted on a $\log _{10}-\log _{10}$ basis, that were

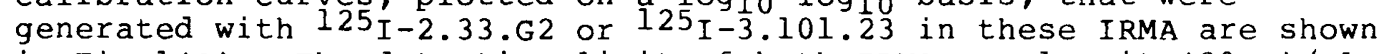
in Fig $l(A)$. The detection limit of both IRMA was 1 unit $(20 \mathrm{pg}) / \mathrm{ml}$ and calibration curves were linear in the range $1-1000$ units/ml. Based on our epitope analysis or rTNF, IRMA were also constructed with different combinations of mutually compatible anti-rTNF McAb pairs of many combinations tested, 3.6.10 rTNF McAb in combination with $125 \mathrm{I} 3.101 .23 \mathrm{rTNF}$ MCAb (Fig I(A); or 2.28.C6 in combination with 125 I 3.101 .23 (not shown) produced the most sensitive IRMA with calibration curves showing linearity in the range $1-2500$ units/ml. An ELISA constructed with rabbit polyclonal anti-rTNF as first 
antibody, 2.33.G2 anti-rTNF McAb as second antibody, and biotinylated anti-mouse Ig plus streptavidin biotinylated horseradish peroxidase complex (Amersham International) as amplifying layers on the sandwich assay was also reasonably sensitive for rTNF. A typical calibration curve is shown in Fig l(B). The detection
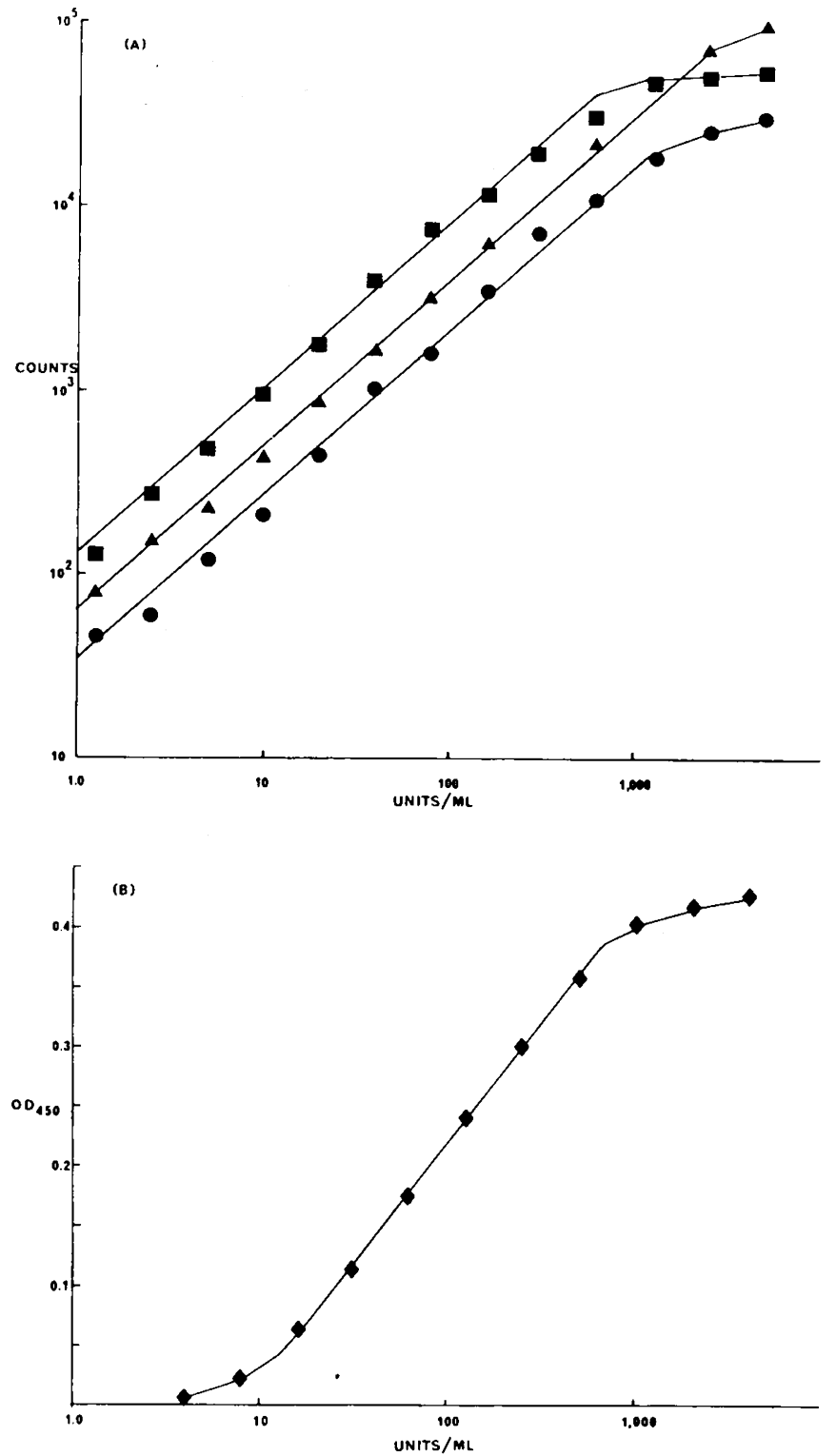

Figure $1(A)$. Calibration curves generated in IRMA with serial two-fold dilutions of purified rTNF ( $1-5000$ units/ml) using rabbit polyclonal anti-rTNF on the bead and $125 \mathrm{I}-3.101 .23, \longleftrightarrow$, rabbit polyclonal anti-rTNF on the bead and 125I-2.33.G2, , and 3.6.10 anti-rTNF McAb on the bead and $125 \mathrm{I}-3.101 .23$, (B) Calibration curve generated in ELISA with serial two-fold dilutions of purified rTNF (1-5000 units/ml) using rabbit polyclonal anti-rTNF on the well and 2.33.G2 anti-rTNF McAb as second antibody, 
limit was approximately 4 units/ml and the calibration curve linear in the range 10-1000 units/ml. Purified 2.33.G2 anti-rTNF McAb could be substituted by other neutralizing anti-rTNF McAbs but non-neutralizing anti-rTNF McAbs were generally less effective (data not shown) for ELISA. Both IRMA and ELISA for rTNF were specific for TNF; neither type of immunoassay detected rLT (Genentech Inc) up to concentrations as high as $5 \times 10^{5}$ units/ml. The high degree of specificity of these IRMA and ELISA for TNF and the development of equivalent immunoassays for LT (Meager, A., in preparation) will allow separate measurement of TNF and LT where these occur together in biological fluids. This is not now possible using conventional bioassays since the biological properties of TNF and LT appear to be indistinguishable.

A great deal of new information about the structure and functions of TNF has accumulated since the cloning of TNF CDNA $(4,5)$. Newly recognised functions of TNF are still being reported, (eg 19) and more must be learned about the role of TNF in immune regulation and inflammatory reactions. The anti-rTNF McAbs reported in this study should prove useful for definitive studies on the biological activities of TNF as well as for their application for immunoassays and further epitope analysis.

\section{ACKNOWLEDGEMENTS}

We are indebted to BASF Knoll AG (Ludwigshafen, FRG) for supplies of highly purified TNF. We thank Dr C. Milstein for the NSO myeloma cell line.

\section{REFERENCES}

1. CARSWELL, E.A., OLD, L.J., KASSEL, R.L., GREEN, S., Fiore, N. and WILLIAMSON, B. (1975) An endotoxin-induced serum factor that causes necrosis of tumours. Proc. Natl. Acad. Sci. USA 72, 3666.

2. MÄNNEL, D.N., MOORE, R.N. and MERGENHAGEN, S.E. (1980) Macrophages as a source of tumoricidal activity (tumor-necrotizing factor). Infect. Immun. 30,523 .

3. OLD, L.J. ( $1985^{\text {) }}$ Tumor necrosis factor (TNF). Science (Washington) 230,630 .

4. PENNICA, D., NEDWIN, G.E., HAYFLICK, J.S., SEEBURG, P.H., DERYNCK, R. , PALLADINO, M.A., KOHR, W.J. , AGGARWAL, B.B. and GOEDDEL, D.V. (1984) Human tumour necrosis factor: precursor structure, expression and homology to lymphotoxin. Nature 312, 724 .

5. MARMENOUT, A., FRANSEN, L., TAVERNIER, J., VAN DER HAYDEN, J., TIZARD, R., KAWASHIMA, E., SHAW, A., JOHNSON, M-J., SEMON, D., MULLER, R., RUYSSCHAERT, M-R, VAN VLIET, A. and FIERS, W. (1985) Molecular cloning and expression of human tumour necrosis factor and comparison with mouse tumour necrosis factor. Eur. J. Biochem. 152,515 .

6. BROXMEYER, H.E., WILliAMS, D.E. , LU, L., COOPER, S., ANDERSON, S.L., BEYER, G.S., HOFFMAN, R. and RUBIN, B.Y. (1986) The suppressive influences of human tumour necrosis factor on bone marrow hematopoietic progenitor cells from normal donors and patients with leukaemia: synergism of tumour necrosis factor and interferon-r. $\mathrm{J}$. Immunol. 136, 4487 .

7. DEGLIANTONI, G., MURPHY, M., KOBAYASHI, M., FRANCIS, M.K., PERUSSIA, B. and TRINCHIERI, G. (1985) Natural killer (NK) cell-derived hematopoietic colony-inhibiting activity and NK cytotoxic factor. Relationship with tumour necrosis factor and synergism with immune interferon. J. Exp. Med. 162, 1512 .

8. ADERKA, D., HOLTMANN, H., TOKER, L. and WALLACH, D. (1986) Tumour necrosis factor induction by sendai virus. J. Immunol. 136, 2938 . 
9. SAYERS, T.J., RANSOM, J.H., DENN, A.C., III, HERBERMAN, R.B. and ORTALDO, J.R. (1986) Analysis of a cytostatic lymphokine produced by incubation of Iymphocytes with tumour cells: relationship to leukoregulin and distinction from recombinant lymphotoxin, recombinant tumour necrosis factor, and natural killer cytotoxic factor. J. Immunol. 137, 385.

10. MURPHY, M., LOUDON, R., KOBAYASHI, M. and TRINCHIERI, G. (1986) $\gamma$-interferon and lymphotoxin, released by activated $\mathrm{T}$ cells, synergize to inhibit granulocyte/monocyte colony formation. J. Exp. Med. $164,263$.

11. RUBIN, B.Y., ANDERSON, S.L., SULLIVAN, S.A. , WILLIAMSON, B.D., CARSWELL, E.A. and OLD, L.J. (1985) Purification and characterization of a human tumour necrosis factor from the LukII cell line. Proc. Natl. Acad. Sci. USA 82, 6637.

12. HAHN, T., TOKER, L., BUDILOVSKY, S., ADERKA, D., ESHHAR, Z . and WALLACH, D. (1985) Use of monoclonal antibodies to a human cytotoxin for its isolation and for examining the self-induction of resistance to this protein. Proc. Natl. Acad. Sci. USA $82,3814$.

13. KOHLER, G. and MLLSTEIN, C. (1975) Continuous culture of fused cells secreting antibody of predefined specificty. Nature 265, 495 .

14. MEAGER, A., PARTI, S., BARWICK, S., SPRAGG, J. and O' HAGAN, K. (1984) Detection of hybridomas secreting monoclonal antibodies to human gamma interferon using a rapid screening technique and specificity of certain monoclonal antibodies to gamma interferon. J. Interferon Res. 4, 619 .

15. SECHER, D.S. (1981) Immunoradiometric assay of human leucocyte interferon using monoclonal antibody. Nature 290, 501.

16. GREENWOOD, F.C. HUNTER, W.T. and GLOVER, J.J. (1963) The

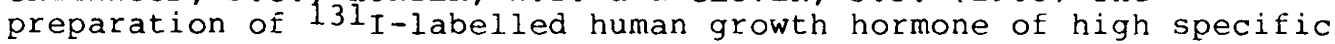
radioactivity. Biochem. J. 89,114 .

17. EY, P.L., PROWSE, S.J. and JENKIN, C.R. (1978) Isolation of pure IgG1, IgG2a and IgG2b immunoglobulins from mouse serum using protein A-sepharose. Immunochemistry $15,429$.

18. SCOTT, G.M., ROBINSON, J.A., SECHER, D.S., ASHBURNER, C.M. and ABBOTT, S.R. (1985) Measurement of interferon from in vitro stimulated lymphocytes by bioassay and monoclonal antibody-based immunoassay. J. Gen. Virol. 66,1621 .

19. TAKEDA, K., IWAMOTO, S., SUGIMOTO, H., TAKUMA, T., KAWATANI, N., NODA, M., MASAKI, A., MORISE, H., ARIMURA, H. and KONNO, K. (1986) Identity of differentiation inducing factor and tumour necrosis factor. Nature 323,338 .

Address reprint requests:

Dr. A. Meager

Division of Immunology

The National Institute for Biological Standards and Control

Holy Hill

Hamstead

London NW3 6RB

UK

Received for publication November 3, 1986.

Accepted after revisions January 27, 1987. 